\title{
MODEL PEMBERDAYAAN KELOMPOK WANITA TANI TERNAK DALAM BUDIDAYA AYAM BURAS DI KECAMATAN BANYUDONO KABUPATEN BOYOLALI
}

\author{
S. H. Purnomo ${ }^{1}$, E. T. Rahayu ${ }^{1}$ dan I. N. Tanti ${ }^{2}$ \\ ${ }^{1}$ Program Studi Peternakan, Fakultas Pertanian, Universitas Sebelas Maret, Surakarta \\ ${ }^{2}$ Sarjana S1, Program Studi Peternakan, Fakultas Pertanian Universitas Sebelas Maret, Surakarta \\ Email: sutrisnohadi@staff.uns.ac.id
}

\begin{abstract}
ABSTRAK
Penelitian mempunyai tujuan untuk mengetahui profil anggota Kelompok Wanita Tani Ternak (KWTT) dalam budidaya ayam buras, mengidentifikasi kebutuhan, faktor pendukung dan faktor penghambat, serta menentukan model pemberdayaan dalam usaha budidaya ayam buras. Penelitian ini dilaksanakan di Kecamatan Banyudono Kabupaten Boyolali, pada tanggal 12 Januari- 5 Maret 2015. Metode yang digunakan dalam penelitian ini adalah metode survei, teknik pengambilan data dalam penelitian ini menggunakan teknik Participatory Rural Appraisal (PRA). Data dari penelitian ini dikumpulkan melalui observasi, wawancara, dan Focus Group Discussion (FGD). Penentuan lokasi penelitian dilakukan secara purposive. Pengambilan sampel penelitian ini ditentukan secara sensus sebanyak 67 orang. Pengambilan data melalui observasi, wawancara dan Focus Group Discussion (FGD) bersama anggota KWTT, Petugas Penyuluh Lapangan (PPL) Dinas Peternakan Kabupaten Boyolali, mitra kerja dan Instansi pendidikan yang terkait. Data penelitian yang diperoleh dianalisis secara deskriptif dan analisis kebutuhan. Faktor pendukung dalam usaha budidaya ini adalah ketersediaan sarana produksi, status kepemilikan ternak, ketersediaan sarana transportasi dan keterlibatan wanita tani dalam aktifitas organisasi, tingkat kesehatan, jaringan kerja/ sosial dan sarana komunikasi. Faktor penghambat dalam usaha ini adalah tingkat pendidikan formal responden dan ketersediaan dan kemudahan akses sarana pendidikan. Faktor kebutuhan wanita tani ternak yang sangat penting ditingkatkan dalam usaha budidaya ayam buras ini adalah tingkat pendidikan formal, ketersediaan dan kemudahan akses sarana pendidikan. Model pemberdayaan wanita tani di Kecamatan Banyudono Kabupaten Boyolali yaitu pembinaan dan pengembangan serta adanya lembaga pendukung.
\end{abstract}

Kata kunci: Model pemberdayaan, kelompok wanita tani ternak, budidaya ayam buras

\section{Model of Empowerment Group of Women Farmer Livestock in The Cultivation of Native Chicken in Banyudono Subdistrict, Boyolali Regency}

\begin{abstract}
This research aim to investigate the profile of women farmers of livestock, supporting factors, inhibiting factors, the needs, and determine the model of empowerment through businesses that are appropriate for Group of Women Farmer Livestock (GWFL) in the cultivation of native chicken in the Banyudono Sub-district, Boyolali Regency. This research was conducted in Banyudono Sub-district, Boyolali Regency on 12 january until 5 march 2015. The method used in this research is the survey method. Intentionally, three villages namely Trayu, Tanjungsari and Bendan were chosen as the research location with the consideration that in these locations have GWFL are still actively contribute to the cultivation of native chicken. Samples were determined by census study to 67 people. The data collection was conducted through observation, interviews and Focus Group Discussion (FGD) with members of GWFL, Extension officer's Boyolali Livestock Service, business partners and
\end{abstract}


associated educational institutions. The data were analyzed by descriptive and analytical needs. The most important of needs factor for women livestock farmer in the cultivation of improved native chicken is the level of formal education, the availability and the conveniences access to educational facilities. The empowerment model of women farmers in Banyudono Sub-distric are providing nonformal education facilities, training and mentoring groups, and build working relationships with partners. The conclusion that can be drawn from this study that the empowerment model applied is the procurement of coaching and developing a native chicken farming as well as cooperation with supporting agencies.

Keyword: Model of empowerment, group of women farmer livestock, native chicken

\section{PENDAHULUAN}

Sub sektor peternakan di Indonesia telah mengalami kemajuan dalam perkembangan pembangunannya. Keberhasilan tersebut berasal dari berbagai faktor pendukung, selain dari Sumber Daya Alam (SDA) yang melimpah, sektor ini juga dipengaruhi oleh kualitas Sumber Daya Manusia (SDM). Kualitas SDM merupakan faktor penentu kelangsungan pelaksanaan pembangunan. Wanita tani merupakan SDM penunjang keberhasilan usaha di sektor ini. Tohir (1983) menyatakan bahwa sumberdaya wanita merupakan salah satu potensi yang besar dalam menyumbang tenaga kerja pada kegiatan produksi dalam usahatani ternak.

Keterbatasan kesempatan kerja dan kurangnya tingkat pengalaman pada wanita, menunjukkan pentingnya pemberdayaan kaum wanita agar mampu menghasilkan SDM yang berkualitas dan berdaya saing tinggi. Pemberdayaan menjadi strategi penting dalam peningkatan peran wanita yang memiliki potensi dan berpeluang mengembangkan kehidupan yang lebih baik (Sumodiningrat, 1999). Pemberdayaan wanita tani ternak di pedesaan dapat dilakukan di berbagai bidang usaha, utamanya adalah bidang pertanian dan peternakan seperti usaha budidaya ayam buras.

Kecamatan Banyudono adalah salah satu Kecamatan di Kabupaten Boyolali yang mempunyai potensi budidaya ayam buras. Populasi ayam buras di Kecamatan Banyudono sebesar 88.420 ekor dengan 8.025 orang peternak, populasi ayam buras tersebut merupakan populasi cukup besar di Kabupaten Boyolali (Badan Pusat Statistik Boyolali, 2014). Ayam buras di Kecamatan Banyudono umumnya dipelihara untuk usaha sampingan.

Petani ternak di daerah ini memiliki lahan luas untuk pengembangan usaha ayam buras, namun pengetahuan tentang budidaya ayam buras masih kurang. Wanita tani ternak di sebagian wilayah Banyudono memiliki perkumpulan dalam sebuah Kelompok Wanita Tani Ternak (KWTT) untuk budidaya ayam buras. Pembentukan KWTT ini akan memudahkan sasaran pemerintah atau instansi dalam memberikan pengetahuan, pelatihan dan keterampilan kepada wanita tani ternak agar mereka dapat menjadi tenaga kerja yang potensial. Profil masyarakat tersebut mendorong peneliti untuk melakukan penelitian tentang model pemberdayaan KWTT dalam usaha budidaya ayam buras di Kecamatan Banyudono Kabupaten Boyolali.

Penelitian ini memiliki beberapa tujuan yaitu untuk mengetahui profil anggota kelompok wanita tani yang mengelola usaha budidaya ayam buras, mengidentifikasi kebutuhan, faktor pendukung dan penghambat anggota kelompok wanita tani ternak dalam usaha budidaya ayam buras, serta menentukan model pemberdayaan wanita tani ternak dalam pengelolaan usaha budidaya ayam buras di Kecamatan Banyudono Kabupaten Boyolali.

\section{MATERI DAN METODE}

Penelitian ini dilaksanakan pada tanggal 12 Januari - 5 Maret 2015 di 
Kecamatan Banyudono Kabupaten Boyolali. Pelaksanaan penelitian menggunakan metode survei terhadap para anggota KWT ayam buras Kecamatan Banyudono Kabupaten Boyolali. Penelitian ini dilakukan dalam dua tahap yaitu tahap pra survei dan survei. Tahap pra survei dilakukan untuk menentukan lokasi penelitian dan menentukan responden. Tahap survei bertujuan untuk mendapatkan data primer dan sekunder melalui wawancara langsung kepada responden dan instansi/lembagalembaga yang terkait dengan penelitian. Penentuan lokasi penelitian dilakukan secara sengaja (purposive sampling) yaitu berdasarkan pertimbangan tertentu sesuai dengan tujuan penelitian (Singarimbun, 1995). Penentuan daerah sampel ini karena Kecamatan Banyudono memiliki populasi ternak ayam buras yang cukup tinggi. Penelitian ini akan dilakukan di tiga desa, yaitu Desa Bendan, Desa Trayu dan Desa Tanjung Sari. Ketiga daerah tersebut memiliki KWT yang aktif berkontribusi usaha budidaya ayam buras di Kecamatan Banyudono.

Metode pengambilan sampel penelitian ini menggunakan sensus. Penelitian sensus merupakan penelitian yang mengambil satu kelompok populasi sebagai sampel secara keseluruhan dan menggunakan kuesioner yang terstruktur sebagai alat pengumpulan data yang pokok untuk mendapatkan informasi yang spesifik (Usman dan Akbar, 2008). Populasi dalam penelitian ini adalah semua angggota Kelompok Wanita Tani (KWT) dari Desa Bendan, Desa Trayu dan Desa Tanjung Sari adalah sejumlah 67 orang.

Metode pengambilan data dalam penelitian ini menggunakan teknik Participatory Rural Appraisal (PRA). Teknik PRA yaitu metode yang menempatkan masyarakat sebagai peneliti, perencana, pelaksana, sebagai penilai dalam program pemberdayaan sehingga peneliti dan stakeholder yang terlibat sebagai fasilitator dan masyarakat sebagai pelakunya (Sidu, 2006). Data dari penelitian ini

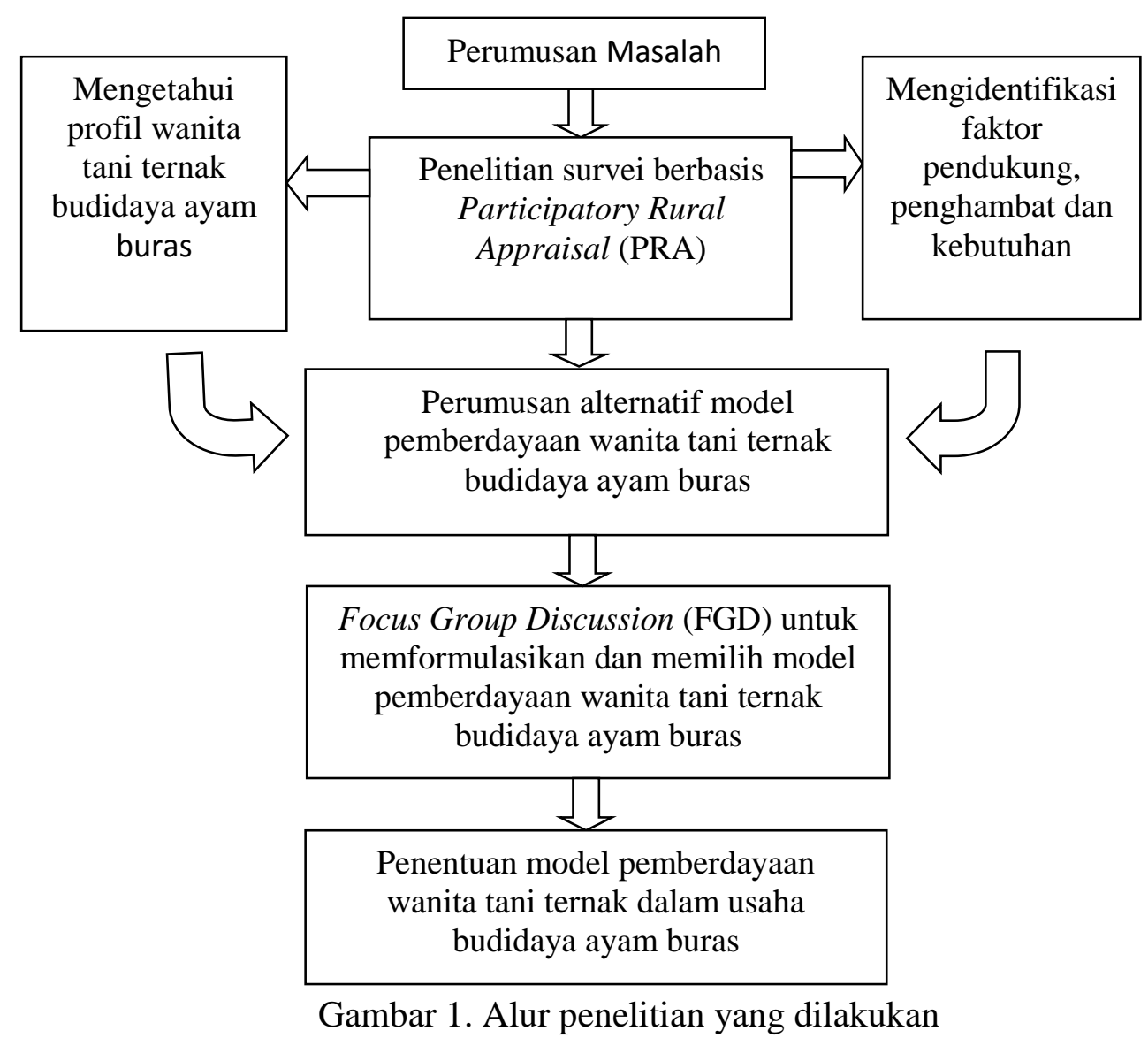


dikumpulkan melalui observasi, wawancara, dan Focus Group Discussion (FGD) bersama wanita tani ternak di Desa Bendan, Desa Trayu dan Desa Tanjungsari Kecamatan Banyudono Kabupaten Boyolali.

Analisis data yang digunakan dalam penelitian ini adalah analisis deskriptif dan analisis identifikasi kebutuhan. Analisis deskriptif dapat menggambarkan keadaan daerah penelitian secara menyeluruh sehingga dapat mengetahui profil anggota kelompok, faktor pendukung dan faktor penghambat usaha budidaya ayam buras di Kecamatan Banyudono Kabupaten Boyolali. Analisis identifikasi kebutuhan masyarakat digunakan untuk menganalisis kebutuhan masyarakat setelah profil anggota kelompok dideskripsikan. Analisis identifikasi kebutuhan adalah proses dimana seseorang mendefinisikan kebutuhan dan memutuskan apa prioritas mereka (McNeil, 1985). Kebutuhan pada dasarnya adalah kesenjangan antara apa yang telah tersedia dengan apa yang diharapkan dan merupakan proses pengumpulan informasi tentang kesenjangan untuk menentukan prioritas dari kesenjangan yang akan dipecahkan. Hal ini merupakan upaya untuk mengidentifikasi kebutuhan anggota KWT budidaya ayam buras sehingga dapat dianalisis untuk mengetahui beberapa faktor pendukung dan penghambat sehingga dapat dilakukan perumusan alternatif model pemberdayaan. Alur penelitian yang akan dilakukan dapat dilihat pada Gambar 1 .

\section{HASIL DAN PEMBAHASAN}

\section{Profil Kelompok Wanita Tani Ternak}

Kelompok wanita tani ternak yang menjadi responden peneliti terdiri dari tiga desa yaitu Desa Trayu, Desa Tanjungsari dan Desa Bendan. Desa Trayu memiliki KWTT yang bernama Bhakti Rahayu dibentuk pada tanggal 10 September 2010 dengan diketuai oleh ibu Suwarni. Kelompok ini berawal dengan beranggotakan 40 orang, kemudian seiring dengan kesibukan pekerjaan sebagai buruh kini tinggal 25 anggota aktif. Kelompok ini aktif mengkuti beberapa aktivitas ternak ayam. Pelatihan-pelatihan dari Dinas Peternakan setempat dan instansi akademis yang pernah diikuti diantaranya adalah pembuatan telur asin, telur bebek asap, budidaya ayam buras dan penetasan telur dengan mesin tetas. Pada tahun 2014 kelompok ini mendapatkan biaya operasional untuk mengembangkan usaha budidaya ayam buras dengan inovasi teknologi mesin tetas dari Peternakan Universitas Sebelas Maret Surakarta. Tahun 2015 usaha ayam buras di KWTT ini mendapatkan bantuan dari Pemerintah Provinsi Jawa Tengah dalam bentuk satu unit kandang semi intensif dengan kapasitas 20 ekor ayam.

Desa Tanjungsari memiliki KWTT dengan nama Ngudi Rejeki yang terbentuk pada 05 Agustus 2004 dengan diketuai oleh ibu Ninik. Awal terbentuknya KWTT pada saat bu Ninik masih menjabat sebagai ketua PKK di Desa Tanjungsari. Bu Ninik adalah motor penggerak kemajuan dari perkembangan wanita di Desa Tanjungsari. Keanggotaan KWTT ini semula adalah 10 orang, kemudian bertambah menjadi 20 orang hingga sekarang yang masih aktif adalah 18 orang anggota. Kelompok ini menjadi sasaran dari Dinas Pertanian dan Peternakan Boyolali, karena merupakan daerah yang potensial usaha tani dan peternakannya. Pelatihan yang diikuti oleh kelompok ini adalah pengolahan hasil ternak pada tahun 2011 di Kecamatan Banyudono. Kelompok ini sama halnya dengan Bhakti Rahayu, pada tahun 2014 mendapatkan pelatihan budidaya ayam buras dengan inovasi mesin tetas dari Instansi Pendidikan yaitu Peternakan Universitas Sebelas Maret Surakarta.

Desa Bendan memiliki KWTT yang lebih berpengalaman dari kedua KWTT sebelumnya, hal ini dikarenakan KWTT yang diberi nama Ngudi Raharjo ini telah berdiri sejak 05 Desember 1986. Pengalaman beternak ayam buras yang cukup lama menghasilkan budidaya ayam buras dikelompok ini mengalami puncak 
Tabel 1. Karakteristik responden anggota KWTT pada usaha budidaya ayam buras

\begin{tabular}{llrr}
\hline \hline Karakteristik Responden & & Jumlah (orang) & Persentase $(\%)$ \\
\hline a. Umur & $15-30$ tahun & 4 & 5,97 \\
& 31-45 tahun & 16 & 23,88 \\
& $46-60$ tahun & 31 & 46,27 \\
& $>61$ tahun & 16 & 23,88 \\
b. Pengalaman Beternak & $1-10$ tahun & 19 & 28,36 \\
& 11-20 tahun & 18 & 26,86 \\
& $>$ 20 tahun & 30 & 44,78 \\
c. Anggota Keluarga & 1-3 orang & 31 & 46,27 \\
& 4-5 orang & 29 & 43,28 \\
& $>5$ orang & 7 & 10,45 \\
d. Tingkat Pendidikan & Tidak Sekolah & 5 & 7,46 \\
& SD & 32 & 47,76 \\
& SMP & 14 & 20,90 \\
& SMA & 13 & 19,40 \\
& Perguruan Tinggi & 3 & 4.48 \\
e. Pekerjaan & Petani & 5 & 7,46 \\
& Ibu Rumah Tangga & 24 & 35,82 \\
& Buruh & 11 & 16,42 \\
& Swasta & 8 & 11,94 \\
& PNS & 3 & 4,48 \\
& Pedagang & 16 & 23,88 \\
\hline
\end{tabular}

Sumber : Data primer terolah, 2015

kejayaan pada tahun 2000. Keanggotaan dari kelompok ini bermula dari 30 orang hingga sekarang tinggal 24 orang sebagai anggota aktif KWTT. Juara satu lomba ayam buras tingkat kabupaten sudah pernah diraih oleh kelompok ini pada tahun 1994. Pada tahun 2001 lomba tingkat Provinsi Jawa Tengah kelompok ini mendapatkan juara harapan satu. Semakin tahun perkembangan usaha budidaya ayam burasnya semakin menurun, karena kurangnya keuletan anggota yang sudah berusia lebih dari 50 tahun.

\section{Karakteristik Responden}

Karakteristik responden pada usaha budidaya ayam buras dapat dilihat pada Tabel 1. Berdasarkan data pada Tabel 1 umur responden paling banyak pada umur 46-60 tahun yaitu 31 orang $(46,27 \%)$. Ratarata umur responden dalam penelitian ini digolongkan dalam usia produktif. Hasil tersebut didukung pada Undang-Undang Tenaga Kerja Nomor 13 Tahun 2003, seseorang yang dikelompokkan sebagai tenaga kerja berusia 15 sampai dengan 64 tahun (Arsyad, 1999).

Pengalaman beternak responden paling banyak yaitu lebih dari 20 tahun $(44,78 \%)$. Pengalaman beternak menjadi salah satu ukuran kemampuan seseorang dalam mengelolah suatu usaha peternakan. Nitisemito dan Burhan (2004) menyatakan bahwa, semakin banyak pengalaman maka semakin banyak pula pelajaran yang diperoleh di bidang tersebut.

Jumlah anggota keluarga paling banyak adalah 1-3 orang sebanyak 31 responden (46,27\%). Jumlah anggota keluarga petani sangat mempengaruhi sumber persediaan tenaga kerja, tetapi juga merupakan beban hidup yang harus ditanggung dan dinafkahi oleh kepala keluarga petani tersebut. Usaha ternak ayam buras merupakan usaha yang tidak membutuhkan banyak tenaga kerja karena pemeliharaannya relatif mudah.

Tingkat pendidikan responden paling 
Tabel 2. Faktor pendukung anggota KWTT dalam usaha budidaya ayam buras

\begin{tabular}{|c|c|c|c|}
\hline Faktor pendukung & Jumlah orang & Kategori & Persentase $(\%)$ \\
\hline \multicolumn{4}{|c|}{$\begin{array}{l}\text { a. Keterlibatan dalam aktivitas } \\
\text { organisasi sosial }\end{array}$} \\
\hline 1) Jumlah skor 1-2 & 2 & Kurang baik & 2,98 \\
\hline 2) Jumlah skor 3-4 & 58 & Sedang & 86,58 \\
\hline 3) Jumlah skor 5-6 & 7 & Baik & 10,44 \\
\hline \multicolumn{4}{|c|}{ b. Ketersediaan sarana produksi } \\
\hline 1) Jumlah skor 7-11 & 32 & Kurang Baik & 47,6 \\
\hline 2) Jumlah skor $12-16$ & 34 & Sedang & 50,5 \\
\hline 3) Jumlah skor $17-21$ & 1 & Baik & 1,49 \\
\hline \multicolumn{4}{|l|}{ c. Status kepemilikan } \\
\hline 1) Jumlah skor 3-4 & 0 & Kurang Baik & 0 \\
\hline 2) Jumlah skor 5-6 & 8 & Sedang & 11,94 \\
\hline 3) Jumlah skor 7-9 & 59 & Baik & 88,06 \\
\hline \multicolumn{4}{|l|}{ d. Sarana transportasi } \\
\hline 1) Jumlah skor 3-4 & 11 & Kurang baik & 16,42 \\
\hline 2) Jumlah skor 6-7 & 35 & Sedang & 52,24 \\
\hline 3) Jumlah skor 7-9 & 21 & Baik & 31,34 \\
\hline \multicolumn{4}{|l|}{ e. Jaringan kerja/ sosial } \\
\hline 1) Jumlah skor 2-4 & 0 & Kurang baik & 0 \\
\hline 2) Jumlah skor 5-7 & 12 & Sedang & 17,91 \\
\hline 3) Jumlah skor 8-10 & 55 & Baik & 82,09 \\
\hline \multicolumn{4}{|l|}{ f. Sarana komunikasi } \\
\hline 1) Jumlah skor 4-5 & 2 & Kurang baik & 2,99 \\
\hline 2) Jumlah skor 6-7 & 24 & Sedang & 35,82 \\
\hline 3) Jumlah skor 8-10 & 41 & Baik & 61,19 \\
\hline \multicolumn{4}{|l|}{ g. Tingkat kesehatan } \\
\hline 1) Jumlah skor 0-1 & 5 & Kurang baik & 7,46 \\
\hline 2) Jumlah skor 2-3 & 62 & Sedang & 92,54 \\
\hline 3) Jumlah skor 4-5 & 0 & Baik & 0 \\
\hline
\end{tabular}

Sumber : Data primer terolah, 2015

banyak yaitu SD sebesar 32 orang $(47,76 \%)$, sedangkan yang di Perguruan Tinggi hanya 3 orang $(4,48 \%)$. Pendidikan yang tinggi diharapkan memberi dampak pada kinerja usaha peternakan yang semakin berkembang (Siregar, 2009). Soekartawi et al. (1986) menambahkan bahwa, pendidikan seseorang akan mempengaruhi pula dalam menjalankan usaha secara efektif dan efisien.

Mata pencaharian responden mayoritas adalah sebagai ibu rumah tangga sekitar 24 orang $(98,33 \%)$ dari jumlah keseluruhan responden. Penduduk yang bermata pencaharian paling sedikit adalah Pegawai Negeri Sipil (PNS) yaitu 3 orang
$(1,67 \%)$ dari total responden. Profesi sebagai ibu rumah tangga sangat efektif untuk usaha budidaya ayam buras, hal ini dikarenakan waktu yang relatif lebih banyak, sehingga kesempatan pengembangan usaha ternak ayam buras akan lebih tinggi.

\section{Faktor Pendukung Anggota KWTT dalam Usaha Budidaya Ayam Buras}

Faktor pendukung anggota KWTT dalam usaha budidaya ayam buras di Kecamatan Banyudono Kabupaten Boyolali dapat dilihat pada Tabel 2.

Data pada Tabel 2 menunjukkan beberapa faktor pendukung anggota KWTT 
dalam usaha budidaya ayam buras di Kecamatan Banyudono. Faktor pendukung pertama adalah keterlibatan dalam aktivitas organisasi sosial termasuk dalam golongan sedang yaitu $86,58 \%$. Responden yang bermata pencaharian sebagai ibu rumah tangga akan memiliki waktu longgar lebih banyak. Keterlibatan dalam aktivitas organisasi akan membantu responden lebih aktif dalam memperoleh informasi. Faktor kedua adalah ketersediaan sarana produksi seperti luas kandang, jumlah ayam, ketersediaan pakan dan alat-alat peternakan termasuk dalam kategori sedang sebesar $50,75 \%$.

Faktor pendukung ketiga yaitu status kepemilikan ternak yang meliputi ternak milik sendiri, gaduhkan dan milik kelompok termasuk dalam kategori baik sebesar $88,06 \%$. Faktor pendukung keempat adalah ketersediaan sarana transportasi termasuk dalam golongan sedang yaitu sekitar $52,24 \%$. Ketersediaan sarana transportasi yang meliputi kelayakan jalan, kendaraan roda empat dan roda dua dan sepeda dapat digunakan petani dalam mempermudah akses jual beli ternak dan pakan bagi ternak mereka (Rasyaf, 2001).

Jaringan kerja merupakan faktor pendukung kelima, yang mencakup beberapa aspek yaitu kerelaan dalam membangun kerja sama antar sesama, keterbukaan dalam melakukan hubungan atau jaringan kerja dan tingkat motivasi untuk melakukan hubungan sosial (mitra kerja) termasuk dalam golongan baik yaitu sebesar $82,09 \%$, hal ini dikarenakan responden memiliki sikap kerjasama dalam bekerja masih tinggi. Menurut Siagian (2003), peternak yang memiliki jiwa keterbukaan dan motivasi tinggi dalam melakukan hubungan sosial dengan peternak lain akan memberi dampak yang bagus untuk perkembangan dirinya. Faktor keenam adalah ketersediaan sarana komunikasi termasuk dalam golongan baik yaitu sekitar $61,19 \%$.

Faktor pendukung yang terakhir adalah tingkat kesehatan yang meliputi kesempurnaan fisik, peternak di Kecamatan Banyudono tergolong sedang sebesar 92,54\%. Anggota KWTT ini dikategorikan sebagai pekerja aktif, karena dalam usia produktif sehingga untuk beraktifitas dapat berjalan dengan baik. Pernyataan ini sesuai pendapat Swastha dan Sukotjo (1999) bahwa, tingkat produktivitas kerja seseorang akan mengalami peningkatan sesuai dengan pertambahan umur, kemudian akan menurun kembali menjelang usia tua.

\section{Faktor Penghambat KWTT dalam Usaha Budidaya Ayam Buras}

Faktor penghambat KWTT dalam usaha budidaya ayam buras di Kecamatan Banyudono dapat dilihat pada Tabel 3.

Berdasarkan Tabel 3 faktor penghambat anggota KWTT dalam usaha ayam buras terdiri dari dua faktor. Faktor pertama yaitu tingkat pendidikan responden paling banyak adalah pendidikan formal yaitu kurang baik sebesar 55,22\%. Tingkat pendidikan yang kurang baik menyebabkan seseorang kurang memiliki ketrampilan

Tabel 3. Faktor penghambat KWTT dalam usaha budidaya ayam buras.

\begin{tabular}{lccr}
\hline \multicolumn{1}{c}{ Faktor penghambat } & Jumlah (orang) & Kategori & Persentase (\%) \\
\hline a. Tingkat pendidikan formal & 37 & Kurang baik & 55,22 \\
1) Jumlah skor 0-1 & 27 & Sedang & 40,30 \\
2) Jumlah skor 2-3 & 3 & Baik & 4,48 \\
3) Jumlah skor 4-5 & & & \\
b. Ketersediaan dan kemudahan akses & & & \\
sarana pendidikan & 37 & Kurang Baik & 55,23 \\
1) Jumlah skor 4-6 & 29 & Sedang & 43,28 \\
2) Jumlah skor 7-9 & 1 & Baik & 1,49 \\
3) Jumlah skor 10-12 & & & \\
\hline
\end{tabular}

Sumber : Data primer terolah 2015 
Tabel 4. Analisis keberdayaan KWTT dalam model pemberdayaan wanita tani ternak pada usaha budidaya ayam buras.

\begin{tabular}{clccr}
\hline \hline Keberdayaan masyarakat & Jumlah (orang) & Kategori & Persentase (\%) \\
\hline a. & Pengetahuan (kognitif) & 6 & Kurang baik & 8,95 \\
& 1) Jumlah skor 5-8 & 59 & Sedang & 88,06 \\
2) Jumlah skor 9-12 & 2 & Baik & 2,99 \\
$\quad$ 3) Jumlah skor 13-15 & & & Kurang baik & 7,46 \\
b. Sikap (afektif) & 36 & Sedang & 53,73 \\
& 1) Jumlah skor 7-11 & 26 & Baik & 38,80 \\
& 2) Jumlah skor 12-16 & & & \\
3) Jumlah skor 17-21 & 2 & Kurang baik & 2,99 \\
c. Ketrampilan (psikomotorik) & 52 & Sedang & 77,61 \\
& 13 & Baik & 19,4 \\
\hline
\end{tabular}

Sumber: Data primer terolah, 2015

tertentu yang diperlukan dalam kehidupannya. Ahmadi (2003), berpendapat bahwa keterbatasan ketrampilan atau pendidikan yang dimiliki menyebabkan keterbatasan kemampuan untuk masuk dalam dunia kerja. Faktor kedua berhubungan dengan rendahnya tingkat pendidikan formal yaitu ketersediaan dan kemudahan akses sarana pendidikan yang meliputi keberadaan gedung sekolah seperti SD, SMP dan SMA termasuk dalam golongan kurang baik yaitu sekitar 55,23\%. Akses menuju tempat pendidikan terbilang jauh, jarak desa ke SD sekitar 2km, sedangkan jarak SMP dan SMA lebih jauh dari jangkauan. Akses sarana pendidikan yang kurang baik di daerah ini juga akan memberi pengaruh besar pada tingkat pendidikan anggota KWTT tersebut.

\section{Keberdayaan Kelompok Wanita Tani Ternak}

Keberdayaan KWTT meliputi beberapa aspek seperti terlihat pada Tabel 4. Berdasarkan Tabel 4 dapat diketahui bahwa tingkat pengetahuan yang dimiliki peternak termasuk dalam kategori sedang yaitu sebesar 88,06\%. Menurut Arikunto (1994) cit Hamtiah et al. (2012), bahwa tingkat pengetahuan dipengaruhi oleh beberapa faktor yaitu pendidikan, informasi, sosial ekonomi dan budaya, lingkungan, pengetahuan dan usia. Pengetahuan responden tergolong sedang hal ini sesuai dengan pustaka bahwa tingkat pengetahuan akan dipengaruhi oleh faktor pendidikan seseorang, selain itu lingkungan dan usia responden.

Sikap yang dimiliki oleh peternak tergolong dalam kategori sedang sebesar $53,73 \%$. Sikap seseorang akan terbentuk dari sebuah pengalaman dan pengetahuan melalui proses belajar (Sarwono, 2007). Responden memiliki sikap dalam kategori sedang hal ini diperkuat dengan pendapat diatas bahwa faktor pengalaman dan pengetahuan yang menentukan sikap.

Keterampilan yang dimiliki peternak termasuk dalam kategori sedang yaitu $77,61 \%$. Peternak juga harus memiliki ketrampilan dalam beternak agar hasil yang didapatkan memperoleh keuntungan (Soekartawi, 2005). Ketrampilan yang dimiliki oleh responden masih perlu ditingkatkan lagi demi kelangsungan peternakan untuk kedepannya. Pengembangan suatu ketrampilan bisa dilakukan dengan pemberian bekal ilmu dan pelatihan khusus terhadap individu seseorang. 


\section{Faktor Kebutuhan Anggota KWTT dalam Usaha Budidaya Ayam Buras}

Faktor kebutuhan anggota KWTT dalam usaha budidaya ayam buras dapat dilihat pada Tabel 5 .

Analisis kebutuhan anggota KWTT dalam usaha budidaya ayam diambil dari faktor pendukung, faktor penghambat dan keberdayaan masyarakat. Hasil pada Tabel 5 menunjukkan bahwa faktor kebutuhan dalam kategori kebutuhan sangat penting adalah faktor pendidikan formal, ketersediaan dan kemudahan akses sarana pendidikan. Faktor lain adalah ketersediaan sarana produksi, tingkat kesehatan, keterlibatan dalam aktivitas organisasi sosial, pengetahuan, sikap serta keterampilan berada dalam kategori sedang, sehingga penting untuk ditingkatkan.

Perkembangan pendidikan sangat memengaruhi terjadinya proses pembangunan untuk mencapai pertumbuhan yang tinggi menuju tercapainya kesejahteraan masyarakat, demikian dengan perluasan dan kemampuan sistem pendidikan formal perlu diprogramkan dan dilaksanakan secara terarah sehingga dapat disesuaikan dengan kebutuhan pembangunan nasional yang akan dapat menunjang keberhasilan pembangunan dan peningkatan kesejahteraan masyarakat (Tilaar, 2001). Upaya yang dapat dilakukan dalam peningkatan pengetahuan adalah dengan memberikan pendidikan nonformal seperti penyuluhan dan pelatihan agar tercipta individu yang terampil dan mandiri. Pendidikan nonformal kepada anggota KWTT dapat dilakukan pada saat pertemuan rutin dalam kelompok.

Menurut Kurnia (2000), peranan kelompok sebagai kelas belajar adalah sebagai media untuk meningkatkan pengetahuan, keterampilan dan sikap dari anggotanya. Pelatihan dan penyuluhan sendiri dapat dilakukan oleh dinas setempat maupun mitra kerja dari instansi yang berkaitan. Kerjasama dengan mitra akan memberi dampak besar terhadap anggota KWTT untuk meningkatkan faktor kebutuhan dalam kategori sedang seperti ketersediaan sarana produksi ternaknya.

\section{Model Pemberdayaan Masyarakat}

Model pemberdayaan dalam usaha budidaya ayam buras di Kecamatan Banyudono Kabupaten Boyolali ini ditentukan dengan cara Focus Group Discussion (FGD), yaitu diskusi kelompok yang terarah dan dipandu oleh moderator. Model pemberdayaan masyarakat

Tabel 5. Faktor kebutuhan anggota KWTT dalam usaha budisaya ayam buras

\begin{tabular}{|c|c|c|c|}
\hline$\overline{\mathrm{No}}$ & Faktor & Kategori & Kebutuhan \\
\hline \multirow[t]{6}{*}{1} & Pendukung & & \\
\hline & a. Ketersediaan sarana produksi & Sedang & Penting \\
\hline & b. Keterlibatan dalam aktifitas & & \\
\hline & organisasi sosial & Sedang & Penting \\
\hline & c. Tingkat kesehatan & Sedang & Penting \\
\hline & d. Sarana transportasi & Sedang & Penting \\
\hline \multirow[t]{3}{*}{2} & Penghambat & & \\
\hline & $\begin{array}{l}\text { a. Tingkat pendidikan formal } \\
\text { b. Ketersediaan dan }\end{array}$ & Kurang baik & Sangat Penting \\
\hline & $\begin{array}{l}\text { kemudahan akses sarana } \\
\text { pendidikan }\end{array}$ & Kurang baik & Sangat penting \\
\hline \multirow[t]{4}{*}{3} & Keberdayaan KWTT & & \\
\hline & a. Pengetahuan (Kognitif) & Sedang & Penting \\
\hline & b. Sikap (Afektif) & Sedang & Penting \\
\hline & c. Ketrampilan (Psikomotorik) & Sedang & Penting \\
\hline
\end{tabular}

Sumber : Data primer terolah, 2015 
diformulasikan dari analisis faktor Banyudono serta Pegawai Penyuluh kebutuhan anggota KWTT dalam usaha Lapangan (PPL) Dinas Peternakan budidaya ayam buras. Pelaksanaan FGD Kabupaten Boyolali pada tanggal 5 Maret diikuti oleh 67 responden yang berasal dari 2015. Penentuan model pemberdayaan anggota ketiga KWTT di Kecamatan dalam budidaya ayam buras di Kecamatan

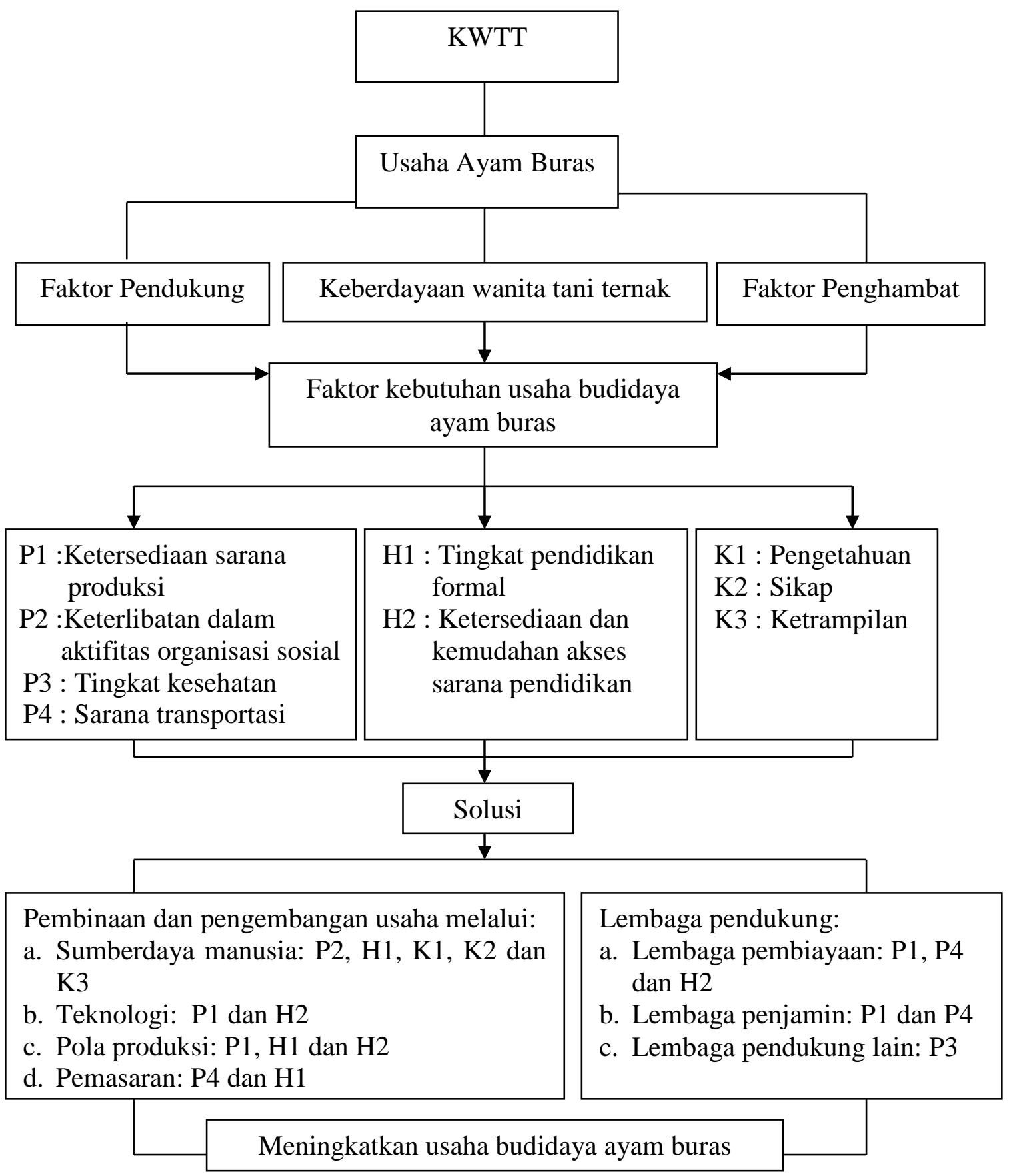

Gambar 2. Alur model pemberdayaan dalam usaha budidaya ayam buras

Keterangan :

P : Pendukung

H : Hambatan

K : Keberdayaan masyarakat 
Banyudono dengan mengaplikasikan pengadaan fasilitas pendidikan nonformal seperti penyuluhan, selain itu juga perlu diadakan pelatihan ketrampilan dan pendampingan kelompok serta adanya relasi kerja antara kelompok dengan mitra khususnya dalam usaha peternakan. Alur model pemberdayaan anggota KWTT dalam usaha budidaya ayam buras di Kecamatan Banyudono, Boyolali dapat diamati pada Gambar 2.

\section{KESIMPULAN}

Berdasarkan hasil penelitian yang telah dilakukan, maka dapat disimpulkan beberapa hal:

a. Profil wanita tani yang mengelola usaha budidaya ternak ayam buras di Kecamatan Banyudono Kabupaten Boyolali adalah sebagian besar berpendidikan SD dan pekerjaan responden yang mendominasi adalah ibu rumah tangga.

b. Faktor pendukung dalam budidaya ternak ayam buras di Kecamatan Banyudono Kabupaten Boyolali adalah ketersediaan sarana produksi, keterlibatan dalam aktifitas organisasi sosial, sarana transportasi ,status kepemilikan ternak, ketersediaan sarana produksi, tingkat kesehatan, jaringan kerja/ sosial, sarana komunikasi. Faktor penghambat dalam usaha budidaya ternak ayam buras di Kecamatan Banyudono Kabupaten Boyolali adalah tingkat pendidikan formal dan ketersediaan serta kemudahan akses sarana pendidikan.

c. Keberdayaan mayarakat berupa tingkat pengetahuan (kognitif) termasuk, sikap (afektif) yang dimiliki oleh peternak dan keterampilan (psikomotorik) beternak tergolong dalam kategori sedang.

d. Faktor kebutuhan wanita tani ternak dalam usaha budidaya ternak ayam buras di Kecamatan Banyudono Kabupaten Boyolali adalah ketersediaan sarana produksi, keterlibatan dalam aktivitas organisasi sosial, tingkat kesehatan, tingkat pendidikan formal, ketersediaan dan kemudahan akses sarana pendidikan, pengetahuan, sikap dan ketrampilan.

e. Model pemberdayaan ditentukan dari faktor kebutuhan anggota KWTT dalam usaha budidaya ayam buras, dengan memberikan pembinaan dan pengembangan usaha budidaya ayam buras dengan peran serta lembaga pendukung.

\section{DAFTAR PUSTAKA}

Arsyad. 1999. Ekonomi Pembangunan. Sekolah Tinggi Ilmu Ekonomi YKPN. Yogyakarta. Badan Pusat Statistik. 2014. Kecamatan Banyudono dalam Angka. Badan Pusat Statistik Boyolali, Boyolali.

Bakir, Z dan C. Manning. 1984. Angkatan Kerja di Indonesia, Partisipasi, Kesempatan dan Pengangguran. Rajawali. Jakarta.

Hamtiah, S., S. Dwijatmoko dan S. Satmoko. 2012. Efektifitas media audio visual (video) terhadap tingkat pengetahuan petani ternak sapi perah tentang kualitas susu di desa indrokilo, kecamatan ungaran, kabupaten semarang. Jurnal Animal Agriculture. 1:2, 332-330.

Kurnia, G. 2000. Pemberdayaan Kelompok Tani dalam Mewujudkan Kemandirian. Biro Perencanaan Departemen Pertanian. Jakarta.

Nitisemito, A. S dan M. U. Burhan. 2004. Wawasan Studi Kelayakan dan Evaluasi Proyek. Bumi Aksara. Jakarta.

McNail, J. 1985. Curiculum A Comprehensive Introduction. Boston.

Rasyaf, M. 2001. Pengolahan Produksi Ayam Pedaging. Kanisius. Yogyakarta.

Sarwono, B. 1992. Beternak Ayam Kampung. Tarsito. Bandung.

Siagian, S. P. 2003. Manajemen Sumber Daya Manusia. Bumi Aksara. Jakarta.

Sidu, D. 2006. Pemberdayaan Masyarakat Sekitar Hutan Lindung Jompi, Kabupaten Muna, Propinsi Sulawesi Tenggara. Disertasi Doktor. Pasca Sarjana. Institut Pertanian Bogor. Bogor.

Singarimbun, M dan S. Efendi. 1995. Metode Penelitian Ekonomi. Obor. Jakarta.

Siregar. 2009. Analisis Pendapatan Peternak Sapi Potong Di Kecamatan Stabat 
Kabupaten Langkat. Skripsi. Universitas Sumatera Utara. Medan.

Soekartawi, A. Soeharjo, J. L. Dillon dan J. B Hardaker. 1986. Ilmu Usahatani dan Penelitian untuk Pengembangan Petani Kecil. Universitas Indonesia Press. Jakarta.

Soekartawi. 2005. Agroindustri dalam Perspektif Sosial Ekonomi. PT. Raja Grafindo Persada. Jakarta.

Sumodiningrat, G. 1999. Pemberdayaan Masyarakat dan Jaring Pengaman Sosial. Gramedia. Jakarta.
Suprijatna, E., A. Umiyati dan K. Ruhiyat.2005. Ilmu Dasar Ternak Unggas. Penebar Swadaya. Jakarta.

Swastha, B dan I. Sukotjo. 1999. Pengantar Bisnis Modern, Edisi 3. Liberty. Yogyakarta.

Tilaar, H. A. R. 2001. Manajemen Pendidikan Nasional. Remaja Rosada Karya. Bandung.

Tohir, K. A. 1983. Seuntai Pengetahuan Tentang Usahatani Indonesia. PT. Bina Aksara. Jakarta.

Usman, H dan P. S. Akbar. 2008. Pengantar Statistik Edisi Kedua. Bumi Aksara. Jakarta. 